\title{
Ethical considerations for field research on fishes
}

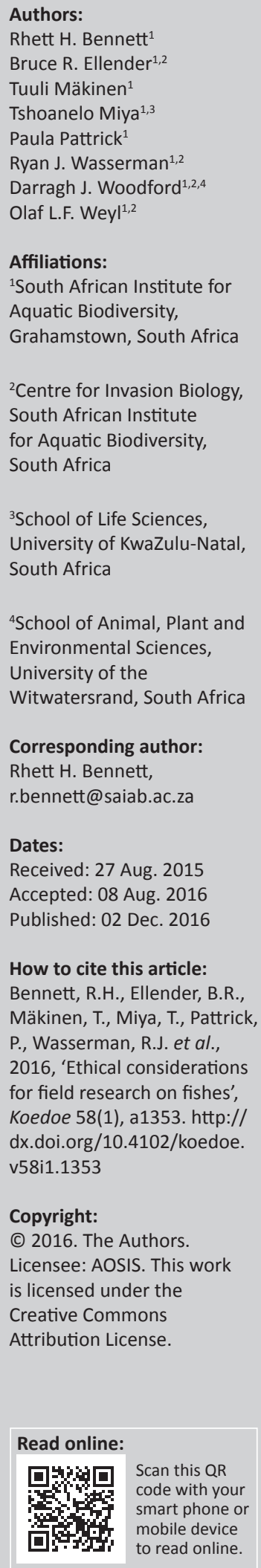

Collection of data from animals for research purposes can negatively impact target or by-catch species if suitable animal ethics practices are not followed. This study aimed to assess the ethical requirements of peer-reviewed scientific journals that publish primary literature on fishes, and review the ethical considerations and animal care guidelines of national and international documents on the ethical treatment of animals for research, to provide an overview of the general ethical considerations for field research on fishes. A review of 250 peer-reviewed, ISI-rated journals publishing primary research on fishes revealed that nearly half $(46 \%)$ had no mention of ethics, treatment of animals or ethical requirements for publication in their author guidelines or publication policies. However, $18 \%$ of the journals reviewed identify a specific set of ethical guidelines to be followed before publishing research involving animals. Ethical considerations for investigators undertaking field research on fishes, common to most animal care policies, legislation and guiding documents, include adhering to relevant legislation, minimising sample sizes, reducing or mitigating pain and distress, employing the most appropriate and least invasive techniques and accurately reporting methods and findings. This information will provide potential investigators with a useful starting point for designing and conducting ethical field research. Application of ethical best practices in field sampling studies will improve the welfare of study animals and the conservation of rare and endangered species.

Conservation implications: This article provides a list of ethical considerations for designing and conducting field research on fishes. By reviewing sampling techniques and processes that are frequently used in field research on fishes and by highlighting the potential negative impacts of these sampling techniques, this article is intended to assist researchers in planning field research to minimise impacts on fish populations. It is envisaged that this review will be a useful resource for journal editorial committees intending to introduce ethical requirements for publication and for researchers, managers, conservation practitioners and research organisations when designing field studies on fishes, applying for ethical clearance and developing institutional ethical guidelines.

\section{Introduction}

Studies on wild populations of animals are integral to scientific research (Basel Declaration Society 2010). Sampling for such research may be non-invasive (e.g. simple observation, visual census and video surveys), intrusive (e.g. external marking, fin-clipping, blood extraction, internal transmitter implantation) or lethal (e.g. voucher specimens, specimens sacrificed for biological and ecological data collection). While intrusive techniques may provide information that is not obtainable via non-invasive methods (Heupel \& Simpfendorfer 2010), such sampling can negatively impact target or non-target (by-catch) species at individual or population levels or damage the surrounding habitat (Animal Behaviour Editorial 2012). Investigators, therefore, need to weigh up the costs and benefits in each case and select sampling methods and experimental procedures that minimise the potential disturbances to target and non-target organisms and their habitat (Canadian Council on Animal Care 2005; South African Bureau of Standards 2008; Use of Fishes in Research Committee 2014).

In much of the world, the humane care and use of animals for scientific purposes is guided by the ethical framework of the three $R$ 's: Replacement of animals by non-animal models where possible; Reduction in the number of animals used to the minimum number required for valid scientific results and Refinement of procedures and animal care standards to minimise pain, suffering, distress or lasting harm (Russell \& Burch 1959). Studies employing sampling of wild populations should therefore eliminate, mitigate or minimise the potential for pain and distress and the duration of exposure to pain (CCAC 2005; Murray \& Fuller 2000; SABS 2008). 
Accordingly, numerous guiding documents have been produced, such as The care and use of animals for scientific purposes (SABS 2008) and Guide for the care and use of laboratory animals (National Research Council 2011), which identify important factors for consideration before and during field sampling studies. Furthermore, certain peer-reviewed scientific journals (e.g. Fisheries Research, Fisheries Management and Ecology and Canadian Journal of Fisheries and Aquatic Sciences) prescribe ethical considerations that need to be met for research involving live animals to be published. However, many journals do not require information on the ethical treatment of study animals, while those that do, lack consistency.

Pain can be defined as 'an unpleasant sensory and emotional experience associated with actual or potential tissue damage' and nociception as 'unconscious detection of potentially injurious stimuli by peripheral, spinal, and subcortical levels of the nervous system' (American Fisheries Society 2014:20-21). Recent research suggests that fishes have highly developed cognitive capabilities and the necessary physiological capacity for pain reception, nociception and suffering, resembling those found in other vertebrate groups (Bshary \& Brown 2014; Chandroo, Duncan \& Moccia 2004). Ethical considerations for research on sentient animals should therefore be applied to fish as they are to other vertebrates (Metcalfe \& Craig 2011). However, many of the guiding documents are largely or entirely directed at the ethical use and treatment of mammalian animals, particularly captive animals (Cooke et al. 2016), with few addressing the ethical use and treatment of fishes, particularly in the wild. Furthermore, because of the diversity of animal taxa under research and the multitude of techniques available, a single set of guidelines is neither practical nor possible (UFRC 2014).

This article aimed to assess the ethical requirements of peerreviewed scientific journals that publish primary literature on fishes and identify the guiding documents most commonly cited in instructions of these journals to submitting authors. The article also aimed to highlight the common ethical considerations for designing and undertaking field research on fishes, with particular relevance to the commonly used techniques in ichthyological and fisheries research in southern Africa. These considerations are based on international and national animal care and use policies and animal ethics guiding documents and published literature. It is envisaged that this review will be a useful resource for journal editorial committees intending to introduce ethical requirements for publication and for researchers, managers, conservation practitioners and research organisations when designing field studies on fishes, applying for ethical clearance and developing institutional ethical guidelines.

\section{Journal ethical requirements for publishing primary fish research}

Scientific journals that publish primary research on fishes were identified through a structured literature search, using the online citation indexing service Web of Science, maintained by Thomson Reuters. A text search for 'fish*', under the research areas of 'fish biology' and 'fish ecology' performed in February 2015 returned articles from more than 500 English-language, ISI-rated journals. The instructions to authors and publication policies of the 250 journals with the most articles relating to fish research were scrutinised to identify their editorial policies relating to the publication of primary research involving the use of animals.

Of the 250 journals reviewed (Appendix 1), 54.0\% (135) have some mention of animal ethics requirements: $18.0 \%(45)$ stipulate a specific guiding document, to which submitted work must adhere for publication (Category 1), 21.6\% (54) require formal approval by an institutional, national or international animal ethics committee (AEC) (Category 2) and $14.4 \%$ (36) require only a statement within the manuscript on the welfare of study animals (Category 3 ). The instructions to authors of the remaining $46.0 \%$ (115 journals), however, make no reference to animal ethics requirements (Category 4 ), suggesting that the treatment of animals in almost half of these articles had not been questioned. A similar review, of 288 randomly selected English-language journals publishing original research on animals, revealed that nearly half the journals assessed had no editorial policy relating to the use of animals in research (Osborne, Payne \& Newman 2009). These two searches therefore highlight the large discrepancies in journal ethical requirements, with almost half not requiring adherence to ethical standards, while journals that do, lack consistency.

The 45 journals that require authors to adhere to a specific set of ethical guidelines (Category 1) together identify 15 guiding documents (Table 1). The scope of these documents varies considerably, from highly prescriptive, for example, Guide for the care and use of laboratory animals (NRC 2011), to providing a general tone for investigators to follow, for example, Basel Declaration (BDS 2010). These included guidelines relating specifically to reporting, such as the ARRIVE guidelines (Animal Research: Reporting of in Vivo Experiments; Kilkenny et al. 2010); national legislation, such as the United Kingdom's Animals (Scientific Procedures) Act 1986; animal use guidelines published specifically by the respective journal (i.e. Animal Behaviour and Journal of Fish Biology) and guiding documents prepared specifically for the ethical treatment of fishes, such as Guidelines on the care and use of fish in research, teaching and testing (CCAC 2005) and Guidelines for the use of Fishes in Research (AFS 2014) (Table 1).

These guiding and policy documents (for web links, see Appendix 2) provide a useful starting point for investigators wishing to explore each of the common aspects for ethical consideration in more detail. While the documents range broadly in their scope, background and applicability, many share several common aspects for ethical consideration (Table 2). These aspects appear repeatedly in most comprehensive animal care and use guiding documents and several countries' legislation relating to the ethical treatment of animals in research. 
TABLE 1: Guiding documents for the ethical treatment of animals in research, stipulated by 45 ISI-rated, peer-reviewed journals that publish primary research on fishes, which must be followed by authors submitting research for publication in these journals.

\begin{tabular}{|c|c|c|}
\hline Guiding document or policy or legislation & Citation & Number journals \\
\hline $\begin{array}{l}\text { National Centre for the Replacement, Refinement and Reduction of Animals in Research: ARRIVE (Animal Research: Reporting } \\
\text { of in vivo Experiments) Guidelines }\end{array}$ & Kilkenny et al. (2010) & 15 \\
\hline Animal Behaviour Journal: Guidelines for the treatment of animals in behavioural research and teaching & Editorial (2012) & 8 \\
\hline $\begin{array}{l}\text { Council for International Organization of Medical Sciences/International Council for Laboratory Animal Science: International } \\
\text { Guiding Principles for Biomedical Research Involving Animals }\end{array}$ & CIOMS \& ICLAS (2012) & 3 \\
\hline Basel Declaration Society: Basel Declaration (2010) & BDS (2010) & 2 \\
\hline United Kingdom Government: Animals (Scientific Procedures) Act 1986 (revised 2013) & UK Government (1986) & 2 \\
\hline Canadian Council on Animal Care: Guidelines on the care and use of fish in research, teaching and testing & CCAC (2005) & 2 \\
\hline Society of Environmental Toxicology and Chemistry: Code of Ethics & SETAC (n.d.) & 1 \\
\hline National Cancer Institute, Frederick National Laboratory for Cancer Research: Animal Care and Use Committee Guidelines & $\mathrm{NCl}$ (n.d.) & 1 \\
\hline Journal of Fish Biology: Ethical justification for the use and treatment of fishes in research & Editorial (2011) & 1 \\
\hline American Fisheries Society: Guidelines for the use of fishes in research & AFS (2014) & 1 \\
\hline The National Academies: The Brazilian legal framework on the scientific use of animals & Filipecki et al. (2011) & 1 \\
\hline National Research Council: Guide for the care and use of laboratory animals & NRC (2011) & 1 \\
\hline
\end{tabular}

TABLE 2: Common aspects for consideration for the ethical treatment of animals in research, mentioned in the guiding documents identified in the author guidelines of $45 \mathrm{ISI}-$ rated journals that publish primary research on fishes, as well as in numerous animal care and use guiding documents and national policies.

\begin{tabular}{|c|c|c|c|c|c|c|c|c|c|c|c|c|c|c|c|}
\hline $\begin{array}{l}\text { Aspects for } \\
\text { consideration }\end{array}$ & ARRIVE & $\begin{array}{l}\text { Animal } \\
\text { Behaviour } \\
\text { Journal }\end{array}$ & $\begin{array}{l}\text { Declaration } \\
\text { of Helsinki }\end{array}$ & $\begin{array}{c}\text { CIOMS } \\
\& \\
\text { ICLAS }\end{array}$ & $\begin{array}{c}\text { Basel } \\
\text { Declaration }\end{array}$ & $\begin{array}{c}\text { EU } \\
\text { Directive } \\
\text { 2010/63/ } \\
\text { EU }\end{array}$ & $\begin{array}{c}\text { UK } \\
\text { Animals } \\
\text { Act } \\
1986\end{array}$ & $\begin{array}{c}\text { Canadian } \\
\text { Council } \\
\text { on } \\
\text { Animal } \\
\text { Care }\end{array}$ & $\begin{array}{l}\text { SETAC } \\
\text { Code of } \\
\text { Ethics }\end{array}$ & $\begin{array}{l}\text { NCL- } \\
\text { Frederick } \\
\text { ACUC }\end{array}$ & $\begin{array}{l}\text { Journal } \\
\text { of Fish } \\
\text { Biology }\end{array}$ & $\begin{array}{l}\text { American } \\
\text { Fisheries } \\
\text { Society }\end{array}$ & $\begin{array}{l}\text { Brazilian } \\
\text { Legal } \\
\text { Framework }\end{array}$ & $\begin{array}{l}\text { European } \\
\text { Convention }\end{array}$ & $\begin{array}{c}\text { National } \\
\text { Research } \\
\text { Council }\end{array}$ \\
\hline
\end{tabular}

\begin{tabular}{|c|c|c|c|c|c|c|c|c|c|c|c|c|c|c|c|}
\hline Legislation & 1 & 1 & - & 1 & - & 1 & 1 & 1 & 1 & - & 1 & 1 & 1 & 1 & 1 \\
\hline Personnel & - & 1 & - & 1 & 1 & 1 & 1 & 1 & - & - & - & 1 & 1 & 1 & 1 \\
\hline Animal welfare & 1 & 1 & 1 & 1 & 1 & 1 & 1 & 1 & 1 & 1 & 1 & 1 & 1 & 1 & 1 \\
\hline $\begin{array}{l}\text { Principle of } \\
\text { the } 3 R^{\prime} s\end{array}$ & 1 & 1 & - & 1 & 1 & 1 & 1 & 1 & 1 & 1 & 1 & 1 & 1 & 1 & 1 \\
\hline $\begin{array}{l}\text { Cost-benefit } \\
\text { analysis }\end{array}$ & 1 & 1 & - & 1 & - & - & - & - & - & 1 & - & 1 & 1 & - & 1 \\
\hline $\begin{array}{l}\text { Endangered } \\
\text { species }\end{array}$ & 1 & 1 & - & - & - & 1 & - & 1 & - & - & 1 & 1 & - & - & 1 \\
\hline Handling & & 1 & - & - & - & 1 & - & 1 & - & - & - & 1 & - & - & 1 \\
\hline Holding & 1 & 1 & - & 1 & - & 1 & 1 & 1 & - & 1 & - & 1 & 1 & 1 & 1 \\
\hline $\begin{array}{l}\text { Standardised } \\
\text { procedures }\end{array}$ & 1 & 1 & - & 1 & - & 1 & 1 & 1 & - & 1 & 1 & 1 & 1 & 1 & 1 \\
\hline $\begin{array}{l}\text { Anaesthesia/ } \\
\text { analgesia }\end{array}$ & 1 & 1 & - & 1 & - & 1 & - & 1 & - & 1 & 1 & 1 & 1 & 1 & 1 \\
\hline Euthanasia & 1 & 1 & & 1 & & 1 & 1 & 1 & & 1 & 1 & 1 & 1 & 1 & 1 \\
\hline $\begin{array}{l}\text { Capture } \\
\text { methodology }\end{array}$ & - & 1 & - & - & - & 1 & - & 1 & - & - & - & 1 & - & - & - \\
\hline $\begin{array}{l}\text { Collecting } \\
\text { fluid/tissue }\end{array}$ & - & - & - & - & - & - & - & 1 & - & 1 & - & 1 & - & - & - \\
\hline $\begin{array}{l}\text { Marking/ } \\
\text { tagging }\end{array}$ & - & - & - & - & - & - & - & 1 & - & - & - & 1 & - & - & 1 \\
\hline Reporting & 1 & 1 & - & - & 1 & - & - & - & - & - & - & - & 1 & - & - \\
\hline
\end{tabular}

The clear and unified theme across almost all guiding documents is the need to maintain the welfare of study animals (Table 2). To this end, many of these guidelines advocate adopting the principle of the three $R^{\prime}$ s - Replace, Reduce, Refine (Russell \& Burch 1959). Most guiding documents also highlight the importance of adhering to regional, national or international legislation and gaining approval from at least a local or institutional AEC, and many identify the requirements and considerations for holding (i.e. keeping in captivity), breeding and husbandry of animals. Specific procedures, such as the sampling of blood or tagging of fishes, receive relatively less focus in these documents, although most documents identify the need for standardised, approved procedures and prescribe that investigators familiarise themselves with the adverse effects associated with different methods and choose the least invasive techniques to suit the aims of the study and the information required (e.g. behavioural observations, genetic studies or specimen collections) (CCAC 2005; UFRC 2014).

The following subsections of this review expand on these common ethical considerations, providing information (with citations to relevant literature) for researchers, managers and conservation practitioners, when undertaking sampling or field research on fishes and for journals intending to develop or specify ethical requirements for publication. Particular focus is placed on the considerations for capture, handling and processing of fishes, which are relatively underrepresented in many guiding documents. 


\section{Ethical considerations for field research on fishes}

Based on the guiding documents identified in the previous section and numerous institutional, provincial, national and international guidelines for the care and use of animals in research, we expand on the key ethical aspects for consideration before, during and after undertaking field research on fishes, which we group into five categories: regulations, experimental design, handling and holding of study animals, experimental procedures and reporting of findings.

\section{Regulations}

Prior to any study involving live animals, investigators should familiarise themselves with the regulations and legislation pertaining to the proposed species, techniques and study area and obtain all necessary permits (Murray \& Fuller 2000). All research activities and field sampling should follow accepted policies, standard operating procedures and international guidelines for the care and use of animals in research (CCAC 2005). In South Africa, animal research is governed by the Veterinary and Para-Veterinary Professions Act (South African Government, Act No. 19 of 1982), with guidelines provided by the South African National Standard (SANS) 10386: The care and use of animals for scientific purposes (SABS 2008). Investigators should also ensure that all methods, sample sizes, target species and study locations are approved by at least an institutional or preferably national or international AEC. All persons involved in the capture, handling, holding, treatment and processing of experimental animals must be appropriately trained for their specific roles during an experimental procedure (Bradford, Korman \& Higgins 2005; Murray \& Fuller 2000).

\section{Experimental design}

\section{Animal welfare, sample size and the principle of the three R's}

The most repeated consideration, in most guiding documents, is to maintain the welfare of the study animals and minimise or mitigate pain, suffering and distress (AFS 2014; CCAC 2005). This may be achieved through less invasive techniques and refining procedures in ways that reduce the intensity and durations of exposure to pain, suffering and distress (Mohr 2013; NRC 2011).

The number of individuals captured, manipulated or killed for the purpose of research is a fundamental consideration of any scientific study involving live animals. The appropriate sample size is contingent on the nature and objectives of the proposed research. Most guiding documents therefore advocate the principle of the three R's (Russell \& Burch 1959). For experimental research, particularly field research in which animal subjects cannot be replaced by computer or other surrogate models, the number of study animals should be minimised as far as practicably possible, but sufficient to provide representative information (UFRC 2014).

\section{Cost-benefit analysis}

A key principle of justifying animal experimentation is that the cost incurred to the individual or population (e.g. stress, deaths) is outweighed by the benefit of the research (e.g. advancement of knowledge) to society (Knight 2011). Thus, in proposed studies for collecting or manipulating fishes, a cost-benefit analysis should underlie decisions regarding sample size (Animal Behaviour Editorial 2012). For biodiversity studies, a sample should be sufficient to capture phenotypic or genotypic variation, although this may be difficult to determine without prior knowledge of a taxon's natural genetic variation (Miyamoto et al. 2008). In experimental biology, a minimum sample size may be determined to satisfy the required statistical power (Knight 2011). Voucher specimen collections should sacrifice the minimum number of animals necessary for effective species confirmation, taking into account sexual dimorphism, ontogenetic change in identifiable features and similarity to related species (Animal Research Review Panel n.d.).

\section{Species and sampling localities}

During field collection, vulnerable life-history stages or lifecycle events, such as aggregations of breeding fish, and sensitive habitats should be avoided (AFS 2014). Species regarded as imperilled or threatened should not be subjected to invasive sampling studies, unless deemed necessary for the specific purpose of gaining information for improved conservation (AFS 2014). By-catch of non-target species should be minimised, but if captured these should be released promptly and with minimal injury (AFS 2014). The number of sampling sites, depending on habitat variation, distribution range and the purpose of collection (e.g. confirming range shifts), should be minimised. Investigators should also select a sampling method that has the least impact on the fishes and the local ecosystem (CCAC 2005).

Recent debate around the conservation ethics of killing endangered species for scientific research highlights the ethical challenge of justifying the lethal sampling of fishes in field work (Heupel \& Simpfendorfer 2010; Minteer et al. 2014). For lethal sampling, particularly of threatened species, the proportion of the population affected by sampling (with implications for the viability of the sampled population) and the purpose of collecting, as it applies to the conservation management of the species, should be considered.

Certain fisheries journals, such as Journal of Fish Biology and Indian Journal of Fisheries, have explicit policies on the sizes and justification of lethal collections reported on in submitted manuscripts and will not accept manuscripts that involve the unmotivated killing or damage of IUCN Red List threatened or endangered species.

\section{Handling, holding and release of experimental fishes}

Captured fish should be handled in a manner that minimises pain, distress, suffering and unnecessary loss of external 
mucus or scales (CCAC 2005). The duration of handling and the experimental procedure should be kept to a minimum, to avoid unnecessary stress and exposure time (AFS 2014).

Investigators should assess the suitability of holding study animals prior to, during or after experimentation. If holding tanks are to be used, they must allow fish to rest comfortably, minimise risk of escape or injury, be adequately aerated, maintain constant temperature and minimise the risk of disease transmission (Barker et al. 2002). Holding tanks should be disinfected between uses and holding areas must be safe, quiet and hygienic (Barker et al. 2002). While postexperimentation captivity may allow recovery monitoring, this may be undesirable for species vulnerable to stress from captivity, and holding of animals in field research, particularly large-bodied animals, may be impractical (Jepsen et al. 2002).

Where appropriate, fish should be released as soon as possible after completion of processing (e.g. measuring, tagging or collection of tissue). All fish having undergone an experimental procedure must be in good health when released and able to return to their natural environment with 'normal' physiological and behavioural functioning (Bradford et al. 2005; CCAC 2005). All necessary steps must be taken to prevent predation and injury upon release and the introduction of pathogens or harmful chemicals into the environment (SABS 2008).

\section{Experimental procedures}

\section{Sampling methods for fish larvae}

High levels of natural mortalities and rapid recoveries from population reductions are characteristic events in the early life histories of many fish species (UFRC 2014). It is therefore generally regarded by most ethical standards that the sampling of fish larvae that have not developed beyond exclusive reliance on their own yolk nutrients does not require ethical clearance (Canadian Council on Animal Care 2007). However, according to the SABS (2008), live, sentient non-human vertebrates, including eggs, foetuses and embryos of fish, are to be cared for and used in ways that are judged to be scientifically, technically and humanely appropriate. Furthermore, investigations involving the early life stages of fishes typically require the sacrifice of large numbers of study organisms. Therefore, a precautionary approach should be followed, in which sample sizes and by-catch are minimised, particularly when threatened species constitute the target or possible by-catch species (CCAC 2005).

For fish larvae, killing by immersion in ice or a fixative such as ethanol or formalin is generally acceptable; however, this should be preceded by an overdose of an appropriate anaesthetic (Craig 2006). Any proposed non-use of anaesthesia on the grounds of compromising the aim of the study should be fully justified a priori (Metcalfe \& Craig 2011). When fish larvae become independently feeding forms, ethical authorisation must be obtained (CCAC 2007).

\section{Non-invasive fish sampling techniques}

Visual sampling, such as underwater visual census (by snorkelling or SCUBA) and underwater video surveys, is common in marine, estuarine and freshwater environments (Ellender et al. 2012; Willis, Millar \& Babcock 2000) and provides a valuable tool for collecting qualitative and quantitative fishery-independent data on fish density, diversity, community structure and behaviour (Brock 1982). Underwater videography is increasingly used for assessing and monitoring fish communities, as digital video provides standardised methodology and permanent records (Langlois et al. 2010). The non-destructive nature of these methods makes them suitable for sensitive habitats and protected areas (Mallet \& Pelletier 2014), and in most cases, ethical justification for their use is not necessary. In some instances, however, divers conducting visual or video observations or the deployment of remote equipment may cause habitat damage. Investigators should thus attempt to minimise any potential impact on the habitat.

\section{Capture sampling techniques}

Numerous sampling techniques involve the actual capture (such as trapping, netting or hooking) of target fishes and are thus inherently invasive. Investigators therefore need to understand the uses, limitations and threats of these methods, in order that the most appropriate method be employed, to provide the most satisfactory result, while minimising pain, suffering and distress (EU 2010).

Netting: There are a variety of netting methods for the capture of fishes, some passive and some active. Gill nets are passive nets, hung vertically in the water column. The gills or fins of fish swimming into the net become entangled in the mesh, preventing their escape. Mesh size is an important consideration, as larger mesh sizes usually result in the capture of larger fish, while providing some form of exclusion for smaller species or individuals. The use of gill nets for sampling is generally accepted, although gill nets can result in cuts on the body from the filament of the net or the drowning of obligate air-breathing fishes, amphibians, reptiles and mammals (Ellender et al. 2016).

Fyke nets are also passive nets, comprising a vertical wall of net that guides fishes into an enclosed cod-end or bag at either end. They are generally considered non-destructive, as fish are free to swim in the cod-end once captured, allowing them to be released relatively unharmed. However, fyke net placement is an important consideration, as nets set in areas of low oxygen concentration can result in elevated fish mortality. Furthermore, fyke nets are not species selective and mortality of by-catch, particularly drowning of obligate air-breathing animals, can occur (Larocque, Cooke \& BlouinDemers 2012). Mortality can also result from predatory fishes, frogs or crabs that are caught in the cod-end or from external sources, such as otters attacking fishes through the net (Ellender et al. 2016). Given the associated predation risk to captured fishes, fyke nets may be unsuitable in certain environments, particularly if they pose a high capture threat 
to endangered species. Simple gear modifications, such as creating air spaces using floats to allow captured animals to breathe (Larocque et al. 2012) or selective mesh placed over the entrance to exclude mammals or reptiles, can however reduce mortality and by-catch. Reducing soak time or checking nets at shorter intervals enables by-catch and target species to be processed and released more rapidly. Owing to the potential injuries, by-catch and mortalities associated with gill and fyke netting, motivation for their use is warranted and identification of potential by-catch species and an assessment of their conservation status should form an integral part of the planning phase of any project using these gears.

Active net gears include, inter alia, seine nets and various forms of trawl nets. Seine nets are vertical nets, with a floating top line and weighted bottom line, actively hauled to encircle a set area of water and pull the fish within that area to shore. They are a preferred gear for sampling fish communities in shallow littoral environments such as beaches, estuaries and artificial impoundments (Lapointe, Corkum \& Mandrak 2006). A cod-end at the centre of the net acts as a corral point for fish as they are brought to shore. Seine netting is generally regarded as non-destructive, although mortality of smallbodied species and post-release mortality of discarded bycatch species have been recorded (Kennelly \& Gray 2000). Fish mortality can be minimised by handling fish within the submerged cod-end before bringing the net onshore. In some cases, seine netting can damage submerged macrophyte habitat in haul regions, although the impact is usually minor (Bayley \& Herendeen 2000).

Trawling refers to nets towed from a boat, which usually sample hyper-benthic environments. The use of dragged or towed gears, which may damage the habitat, benthic environment or animals sampled (Feyrer et al. 2013), should be avoided or minimised (UFRC 2014). Alternative methods should also be sought where possible; for example, Feyrer et al. (2013) investigated the use of attaching a camera to the open cod-end of a trawl net, allowing fish to be recorded but to pass through the net unharmed, greatly reducing mortality.

Electrofishing: Electrofishing is one of the most effective and commonly employed sampling methods in shallow freshwater environments (Snyder 2003). While generally considered non-destructive, it can have negative impacts (Snyder 2003). In extreme cases, severe spinal injuries, internal haemorrhages, bleeding at the gills, physiological stress, asphyxiation and harmful effects on embryos have been recorded (Snyder 2003). It is therefore recommended that researchers familiarise themselves with, and apply, recommendations for international best practises regarding electrofishing (e.g. Beaumont et al. 2002; Goodchild 1991). Current strengths and settings and the electrofishing gear itself should be suited to the target species and conditions in the study area, such as conductivity, water depth and survey area (Bohlin et al. 1989). When sampling threatened or endangered fishes, electrofishing should be used with caution and alternative methods employed where possible (Ellender et al. 2012). If multiple electrofishing passes are intended, all fish captured should immediately be removed from the net and placed in aerated buckets, filled with ambient water, to avoid prolonged exposure. Bohlin et al. (1989) and Snyder (2003) provide comprehensive reviews on standardising electrofishing protocols and harmful effects of electrofishing.

Hook-and-line fishing: Hook-and-line fishing is commonly used in a range of research applications, such as quantifying abundance, assessing community structure and for tagging studies (Bennett \& Attwood 1993; Dunlop, Mann \& Van der Elst 2013; Willis et al. 2000). Catch-and-release is often employed, whereby fishes are released to the capture environment after undergoing procedures such as measuring or tagging, with minimal impact to the fishes and environment (Cooke et al. 2013a). However, excessive fight times or postcapture air exposure and high water temperatures have been shown to induce physiological stress responses in hook-andline caught fishes, with implications for their successful release (Cooke \& Suski 2004). In addition, fish captured by hook-and-line fishing may be subjected to stress as a result of barotrauma injuries if rapidly brought to the surface (Keniry et al. 1996), or damage to the gills or viscera through hook ingestion (Domeier, Dewar \& Nasby-Lucas 2003). The potential impacts of hook-and-line fishing should thus be thoroughly considered before using this method to capture endangered species or in excessive water depths where barotrauma is likely.

Relevant mitigation measures, such as choice of hook design and size, optimal fishing times and minimised handling times need to be considered (see Cooke \& Suski 2004). The use of circle hooks has been shown to decrease the incidence of gut- or deep-hooking (Cooke \& Suski 2004) and postrelease mortality (Prince et al. 2007) and the use of barbless hooks can reduce injury and facilitate hook removal (Schaeffer \& Hoffman 2002). Brownscombe et al. (2016) provide guidelines for best practice in catch-and-release recreational fisheries.

\section{Ichthyocides}

Ichthyocides (poisons) and anaesthetics have been used extensively to determine fish species composition, particularly in freshwater and shallow reef environments (Ackerman \& Bellwood 2000; Willis 2001). Rotenone, for example, is a commonly used ichthyocide, highly effective at killing most fish species (AFS 2014; Willis 2001). Although such techniques are effective for assessing cryptic species and provide greater species and family counts than nondestructive methods (Willis 2001), they can cause excessive mortality for sensitive species, are non-selective, vary widely in effectiveness, provide inefficient sampling of highly mobile species and cannot be used in sensitive areas or where sampling is to be repeated (Brock 1982). Furthermore, recent studies have highlighted that many non-target organisms are susceptible to ichthyocide concentrations used for fishes (e.g. Dalu et al. 2016). Careful consideration, especially of collateral impacts on non-target biota, is therefore necessary, prior to 
using ichthyocides. Clearwater, Hickey and Martin (2008) discuss several ichthyocides for pest control; however, a comprehensive review of ichthyocides and their use in fish research is lacking.

\section{Anaesthesia and analgesia}

Sedatives or anaesthetics are commonly prescribed and used during prolonged or invasive procedures, to immobilise fish and reduce pain and physiological stress related to capture, handling and processing, through depression of the nervous system (CCAC 2005; UFRC 2014). Minor procedures usually require mild sedation, whereas intrusive (major) procedures, such as laparotomy, usually require deep anaesthesia (Thorsteinsson 2002). Where anaesthetics or sedatives are used, only approved drugs should be used and administered at a concentration and duration appropriate to the size and species of fish and in accordance with established guidelines and relevant legislation (AFS 2014; UFRC 2014).

The SANS 10386 (SABS 2008) recommends four anaesthetics for use on fishes in South Africa, including tricaine methanesulfonate (MS-222), benzocaine (and benzocaine hydrochloride), metomidate and ketamine hydrochloride. However, none of these is registered in Australia, New Zealand, the United States, Canada or Europe (Javahery \& Moradlu 2012). Other anaesthetics common in fish research include 2-phenoxyethanol, clove oil, AQUI-S ${ }^{\mathrm{TM}}$ (active ingredient isoeugenol) and quinaldine sulphate (Javahery \& Moradlu 2012; Wagner \& Cooke 2005). However, many of these are regarded as hazardous (Javahery \& Moradlu 2012), particularly if fish are released and subsequently consumed by humans (Thorsteinsson 2002). Of these anaesthetics, only MS-222 is approved by the United States Food and Drug Administration (FDA) for use on animals in the United States (AFS 2014), but has a 21-day withdrawal period before fish can be released into the wild, negating its use in field studies. Eugenol (a derivative of clove oil) and carbon dioxide are the only immediate-release drugs approved by the FDA (AFS 2014) - yet neither is recommended for use in South Africa (SABS 2008), and carbon dioxide allows considerable trauma at shallow sedation and is not suitable for heavy sedation required in invasive procedures (Javahery \& Moradlu 2012). Therefore, identifying an appropriate drug and concentration, particularly for fish intended for immediate release, is often a challenging task and should be based on thorough research of contemporary literature and legislation prior to any implementation (see Thorsteinsson 2002 for comprehensive review of anaesthetics).

Anaesthetics can induce prolonged negative metabolic effects and stress responses in fishes (CCAC 2005), as well as hypoxia from reduced respiration and vascular activity (Thorsteinsson 2002). In certain cases, this may lead to post-release mortality or increased predation risk (Cooke et al. 2005). Numerous studies on fishes, involving handling and even invasive procedures such as laparotomy, have deemed the use of anaesthesia inappropriate (Wagner \& Cooke 2005). For large elasmobranchs, anaesthesia would require specialised lifting equipment, considerable risk to the animals and excessive quantities of chemicals; therefore, such studies usually rely on tonic immobility (e.g. Holland et al. 1999). Therefore, the use of anaesthetics should be evaluated prior to any study (Thorsteinsson 2002), particularly when fish are planned for release into the wild and in some cases may not be appropriate at all (Cooke et al. 2013b, 2016).

\section{Collecting tissue and blood samples}

Tissue collection: A variety of methods have been used to successfully collect tissue or blood samples from anaesthetised fish without significant effects on their survival. Non-lethal tissue sampling includes fin-clipping, excision of scales and gill, muscle or skin biopsies (McCormick 1993; UFRC 2014). Fin-clipping is common for genetic sampling and its deleterious effects have been extensively studied. Many studies reported no negative effects and complete regeneration of the affected fins in weeks (Woodall, Koldewey \& Shaw 2011), while others reported some decrease in survival or growth of fin-clipped fish (O'Grady 1984). The appropriate site to sample is species specific. For example, partial clipping of the dorsal fin was successfully used for genetic sampling of seahorses with no significant effect on mortality (Woodall et al. 2011).

Blood collection: Fish blood is collected for various reasons, such as haematology and clinical chemistry tests (Satheeshkumar et al. 2012), parasitological investigations (Shahi et al. 2013) and investigations on adaptations to subzero temperatures (Miya et al. 2014). Such studies have demonstrated that blood samples can be successfully obtained, even from fish less than $100 \mathrm{~g}$ in mass, without compromising their survival. Plastic syringes with a small volume of anticoagulant such as sodium or ammonium heparin or sodium citrate can be used to avoid the rapid clotting that can occur with the use of glass syringes (Stoskopf 1993). The size of the syringe and diameter of needle should be appropriate to the size of fish. The preferred site for blood sampling from anaesthetised fish is the caudal vein running beneath the vertebrae, using a lateral or ventral approach. Study objectives will determine the required blood volume and concentration of anticoagulant. Other methods used to collect blood from fishes include cardiac puncture and caudal bleeding (UFRC 2014). These methods, however, can compromise the survival of the fish. Needles are most effective when new and sharp and should be replaced or sterilised after each sample to avoid contamination and unnecessary injuries to the fish.

\section{Marking and tagging of fishes}

Marking (using dyes or fin-clipping) and tagging of fishes with external or internal tags has been used extensively to estimate population sizes, discriminate stocks, identify migration rates and movement patterns and assess fish growth and survival (McFarlane, Wydoski \& Prince 1990). Numerous marking and tagging methods are used, although most are intrusive to some degree (Thorsteinsson 2002). The capture, handling and marking/tagging process can affect 
the behaviour, physiology, swimming capacity, predator avoidance, feeding, growth rate and ultimate survival of tagged organisms (Naef-Daenzer et al. 2005; Thorsteinsson 2002). Studies should therefore aim to minimise these impacts, for the welfare of the study animal, to ensure that the process provides scientifically valuable data, and to maximise the value from every individual that has been subjected to the stress of capture, handling and processing (Cooke et al. 2013b).

Marking: Marking techniques for fishes, such as external dyes, fin-clipping, hot branding (e.g. lasers) and freeze branding (e.g. liquid nitrogen), do not breach the skin or musculature and are thus generally considered to have minimal impact on fishes (Murray \& Fuller 2000). However, such marks usually exhibit short-term retention, and brightly coloured external marks or dyes (and any external part of a tag) should be avoided, as these can affect social structure or interactions of the fish or reduce its predator avoidance or hunting capabilities (Guy, Blankenship \& Nielsen 1996; Murray \& Fuller 2000). Chemical tags are another form of marking and may be natural (i.e. accumulation from the local environment) or induced, through immersion, injection or ingestion of chemicals, which become incorporated into tissue or calcified structures (Nielsen 1992). Chemical tagging is long lasting and allows large numbers of individuals to be tagged and does not necessarily require anaesthetic or even handling (Guy et al. 1996), but often requires sacrifice of the animal at a later stage.

General tagging considerations: To minimise the effects of tags on fish and maximise data collection and tag retention, tag size and weight should be appropriate for the size, weight and species of fish (Cooke et al. 2011; Stasko \& Pincock 1977). The tag placement and attachment method must also be appropriate for the study species (Naef-Daenzer et al. 2005; SABS 2008) and have minimal influence on the posture, buoyancy, locomotion (Stasko \& Pincock 1977), behaviour, growth and survival of the fish (Bradford et al. 2009). Where necessary, the suitability of a chosen tag type, size and attachment method should be assessed prior to tagging studies on a new species (CCAC 2005; Murray \& Fuller 2000).

External tag attachment: External attachment is used for simple plastic or wire tags and electronic transmitters and requires that an external or trailing part of the tag be anchored somehow within the musculature or skeletal structure of the fish. A common type of external tagging, particularly in southern Africa, is dart tagging (Maggs \& Cowley 2016). Dart tags are inserted using a sharp, sterile tag applicator, usually at the base of the dorsal fin and anchored behind the pterygiophores (Attwood 1998). Electronic tags can also be attached externally in a similar manner or with wires or nylon cords inserted through the dorsal musculature of the fish and secured with a plastic or metal plate (Liedtke \& Rub 2012; Thorstad et al. 2013). Sharks and large pelagic fishes are often tagged in situ in the water, by means of a dart tag or electronic tag attached to the end of a sharpened pole. For pelagic sharks, tags (particularly satellite tags) are also commonly attached by means of plastic or metal bolts through the dorsal fin (Thorsteinsson 2002).

External tagging is simple and does not necessarily require animals to be anaesthetised, or even brought out of the water (Thorsteinsson 2002). External tags, however, can have negative impacts, as they may increase drag and impede normal swimming ability and reduce growth or survival (Murray \& Fuller 2000). The attachment mechanisms breach the skin and musculature and could lead to infection, tissue damage or necrosis, reduced growth or reduced reproductive capacity (Thorsteinsson 2002). External tags, particularly larger volume electronic tags, should thus be shaped and attached in such a way that minimises drag, entanglement in aquatic vegetation, irritation and constriction (CCAC 2005; Murray \& Fuller 2000). Owing to the disadvantages of external tag attachment, a number of internal tag implantation techniques have been used.

Gastric insertion: Gastric insertion of devices involves voluntary ingestion of the device embedded in bait or the forcing of the device down the pharynx, past the cardiac sphincter and into the stomach by means of a glass or plastic rod (Liedtke \& Rub 2012; Thorsteinsson 2002). The process is less invasive than surgical implantation (Winger \& Walsh 2001), and the internal device overcomes many of the problems associated with external tags, such as entanglement, drag or wound development (Stasko \& Pincock 1977). However, gastric insertion can only be used when fish are not feeding and there are several drawbacks to the technique. There is a risk of tag loss through regurgitation, the presence of the device may affect the ability of the fish to feed and injury may be caused to the oesophagus or stomach (Thorstad et al. 2013; Winter 1996). Furthermore, gastric insertion cannot be used on fishes with a food-crushing pharyngeal apparatus, and the process does not allow for long-term tag retention (Stasko \& Pincock 1977).

Surgical implantation of tags or devices: Laparotomy (the surgical implantation of a device through an incision in the body wall) is becoming recognised as a superior technique to external attachment and gastric insertion, particularly for long-term tag retention, reduced long-term physiological stress and data that may be more representative of normal behaviour (Cooke et al. 2011; Thorstad et al. 2013). The technique is considered to have little or no methodological bias in the long-term, and the internal placement of the tags removes the potential entanglement and hydrodynamic interference that may result from external tags (Jepsen et al. 2002; Thorstad et al. 2013). However, the recovery time after surgical implantation may be greater than that for external attachment or gastric insertion (Thorsteinsson 2002). Furthermore, this process requires suitably trained or qualified personnel and is governed in certain states by formal legislation. In South Africa, surgical procedures are regulated under the Veterinary and Para-Veterinary Professions Act (SA Government, Act No. 19 of 1982). For all tagging procedures, aseptic technique should be maintained, although this is difficult in most field settings. 
Antibiotic powder (topical) or liquid (topical or by injection) can be applied post-tagging to prevent secondary infection. Before releasing tagged fish back into their natural environment, they should be monitored until having recovered from the effects of anaesthesia and surgery.

\section{Euthanasia}

Where the sacrifice of study fish cannot be avoided (e.g. voucher specimen collection or physiological studies), humane euthanasia techniques should be used (SABS 2008). Animals may be euthanised by chemical or physical methods, and the selected methods should be predictable, minimise pain and stress, produce rapid loss of consciousness and be compatible with the scientific aims (American Veterinary Medical Association 2013; SABS 2008). Fishes to be preserved should be euthanised prior to immersion in formalin or other preservatives (CCAC 2005). Where feasible, euthanasia should consist of a two-step process with initial anaesthesia until loss of equilibrium, followed by a physical or chemical method to cause brain death (CCAC 2005). Rapid cooling, followed by prolonged exposure in ice-cooled water, is recommended for small-bodied fishes (AVMA 2013). Overdosing with anaesthetics, such as MS-222, is an accepted method (Neiffer \& Stamper 2009), whereas the use of carbon dioxide, suffocation (removal from water) and decapitation alone are generally not. The AVMA (2013) provides comprehensive guidelines on euthanasia of animals.

\section{Reporting}

Equally important as study design, animal welfare and appropriate methodologies in animal research, are the accurate, comprehensive reporting and communication of procedures, protocols and results, to facilitate knowledge transfer (Filipecki et al. 2011). To this end, the ARRIVE guidelines were developed to ensure that all relevant information is included in publications, to maximise the value of publications and render them useful for scientific advancement or policy making (Kilkenny et al. 2010). Such information may include (inter alia) numbers, demographics and sources of study subjects; sampling localities and times; detailed processing methods; reagent concentrations; holding conditions; statistical tests; positive and negative outcomes; limitations; new discoveries; and applicability of results beyond the specific study (Kilkenny et al. 2010).

\section{Conclusion}

The review of journal ethical requirements revealed considerable variability in the level of ethical reporting for research involving animals to be accepted for publication. While publishers, research institutions and government agencies may vary in their requirements for demonstrated ethical behaviour, such inconsistency should not deter investigators from taking individual responsibility for their ethical duties in sampling or manipulating fishes in the field. The principles of animal welfare and biodiversity conservation should always guide the development of research project methods, regardless of whether they are required by the journal in which an investigator wishes to publish.

To aid this principle, this review highlights both the common guiding documents on the ethical treatment of animals (particularly fishes) and common, important ethical considerations for managers, researchers, technicians and students, as they apply to commonly used methods for fieldbased research on fishes. Primary ethical considerations are that (1) all field, capture, sampling and processing activities must adhere to relevant legislation and should be approved by at least an institutional AEC, (2) the welfare of the study animals should be of primary concern and all efforts should be made to prevent or reduce pain, suffering and distress, (3) sample sizes should be kept to the minimum, but sufficient to achieve the objectives of the study, (4) the conservation status of the target organism should be considered, (5) destructive or invasive gears and processes should be applied with caution and (6) standard and accepted procedures should be followed. The review will provide a useful resource for journal editorial committees developing ethical guidelines for publication and for potential investigators designing and conducting field research on fishes. Application of these ethical requirements in field sampling studies will improve fish welfare and the conservation of fishes, especially rare and critically endangered species.

\section{Acknowledgements}

The authors thank Mrs Sally Schramm, SAIAB Senior Librarian, for assisting with the journals search protocol. Two anonymous reviewers are also thanked for considerable constructive input, and Taryn Murray is thanked for commenting on and proofreading the final version.

\section{Competing interests}

The authors declare that they have no financial or personal relationships which may have inappropriately influenced them in writing this article.

\section{Authors' contributions}

R.H.B. was the lead author and O.L.F.W. was the project leader. R.H.B., B.R.E., P.P., T. Mäkinen, T. Miya, R.J.W., D.J.W. and O.L.F.W. contributed to conceptualisation, analyses, writing and editing the manuscript.

\section{References}

Ackerman, J.L. \& Bellwood, D.R., 2000, 'Reef fish assemblages: A re-evaluation using enclosed rotenone stations', Marine Ecology Progress Series 206, 227-237. http:// dx.doi.org/10.3354/meps206227

American Fisheries Society, 2014, 'Guidelines for the use of fishes in research', American Fisheries Society, Bethesda, MD.

American Veterinary Medical Association, 2013, 'AVMA guidelines for the euthanasia of animals: 2013 edition', American Veterinary Medical Association, Schaumberg.

Animal Research Review Panel of the New South Wales Provincial Government, n.d., 'Collection of voucher specimens', viewed 25 August 2015, from http://www. animalethics.org.au/policies-and-guidelines/wildlife-research/voucherspecimens

Attwood, C.G., 1998, 'Tagging the correct way', The Fishing Journal 1, 23-26. 
Barker, D., Allan, G.L., Rowland, S.J. \& Pickles, J.M., 2002, A guide to acceptable procedures and practises for aquaculture and fisheries research, NSW Fisheries Animal Care and Ethics Committee, Orange.

Basel Declaration Society, 2010, Basel Declaration: A call for more trust, transparency and communication on animal research, Basel Declaration Committee, Basel.

Bayley, P.B. \& Herendeen, R.A., 2000, 'The efficiency of a seine net', Transactions of the American Fisheries Society 129, 901-923. http://dx.doi.org/10.1577/1548 $8659(2000) 129<0901:$ TEOASN > 2.3.CO;2

Beaumont, W.R.C., Taylor, A.A.A., Lee, M.J. \& Welton, J.S., 2002, Guidelines for electric fishing best practice, R\&D technical report W2-054/TR, Environment Agency, Bristol.

Bennett, B.A. \& Attwood, C.G., 1993, 'Shore-angling catches in the De Hoop Nature Reserve, South Africa, and further evidence for the protected value of marin reserves', South African Journal of Marine Science 13, 213-222. http://dx.doi. org/10.2989/025776193784287202

Bohlin, T., Hamrin, S., Heggberget, T.G., Rasmussen, G. \& Saltveit, S.J., 1989 'Electrofishing - Theory and practice with special emphasis on salmonids', Hydrobiologia 173, 9-43. http://dx.doi.org/10.1007/BF00008596

Bradford, M.J., Korman, J. \& Higgins, P.S., 2005, 'Using confidence intervals to estimate the response of salmon populations (Oncorhynchus spp.) to experimental habitat alterations', Canadian Journal of Fisheries and Aquatic Science 62, 2716-2726. alterations', Canadian Journal of Fish
$\mathrm{http}: / / \mathrm{dx} . \mathrm{doi} . \mathrm{org} / 10.1139 / \mathrm{f05}-179$

Bradford, R.W., Hobday, A.J., Evans, K. \& Lansdell, M., 2009, CMAR code of practice for tagging marine animals, CSIRO Marine and Atmospheric Research Paper 028 CSIRO, Hobart.

Brock, R.E., 1982, 'A critique of the visual census method for assessing coral reef populations', Bulletin of Marine Science 32(1), 269-276.

Brownscombe, J.W., Danylchuk, A.J., Chapman, J.M., Gutowsky, L.F.G. \& Cooke, S.J., 2016, 'Best practices for catch-and-release recreational fisheries - Angling tools and tactics', Fisheries Science. http://dx.doi.org/10.1016/j.fishres.2016.04.018

Bshary, R. \& Brown, C., 2014, 'Fish cognition', Current Biology 24, R947-R950. http:// dx.doi.org/10.1016/j.cub.2014.08.043

Canadian Council on Animal Care, 2005, Guidelines on: The care and use of fish in research, teaching and testing, Canadian Council on Animal Care, Ottawa.

Canadian Council on Animal Care, 2007, Guidelines on: Procurement of animals used in science, Canadian Council on Animal Care, Ottawa.

Chandroo, K.P., Duncan, I.J.H. \& Moccia, R.D., 2004, 'Can fish suffer?: Perspectives on sentience, pain, fear and stress', Applied Animal Behaviour Science 86, 225-250. http://dx.doi.org/10.1016/j.applanim.2004.02.004

Clearwater, S.J., Hickey, C.W. \& Martin, M.L., 2008, 'Overview of potential piscicides and molluscicides for controlling aquatic pest species in New Zealand', Science for Conservation 283, 5-74.

Cooke, S.J., Crossin, G.T., Patterson, D.A., English, K.K., Hinch, S.G., Young, J.L. et al., 2005, Coupling non-invasive physiological assessments with telemetry to understand inter-individual variation in behaviour and survivorship of sockeye salmon: Development and validation of a technique', Journal of Fish Biology 67, 1342-1358. http://dx.doi.org/10.1111/j.1095-8649.2005.00830.x

Cooke, S.J., Donaldson, M.R., O'Connor, C.M., Raby, G.D., Arlinghaus, R., Danylchuk, A.J. et al., 2013a, "The physiological consequences of catch-and-release angling: Perspectives on experimental design, interpretation, extrapolation and relevance to stakeholders', Fisheries Management and Ecology 20, 268-287. http://dx.doi. org/10.1111/j.1365-2400.2012.00867.x

Cooke, S.J., Nguyen, V.M., Murchie, K.J., Thiem, J.D., Donaldson, M.R., Hinch, S.G. et al., 2013b, 'To tag or not to tag: Animal welfare, conservation, and stakeholde considerations in fish tracking studies that use electronic tags', Journal of International Wildlife Law and Policy 16(4), 352-374. http://dx.doi.org/10.1080/ 13880292.2013.805075

Cooke S.J. \& Suski, C.D., 2004, 'Are circle hooks an effective tool for conserving marine and freshwater recreational catch-and-release fisheries?', Aquatic Conservation: Marine and Freshwater Ecosystems 14, 299-326. http://dx.doi.org/10.1002/ aqc. 614

Cooke, S.J., Wilson, A.D.M., Elvidge, C.K., Lennoz, R.J., Jepsen, N., Colotelo, A.H. et al., 2016, 'Ten practical realities for institutional animal care and use committees when evaluating protocols dealing with fish in the field', Reviews in Fish Biology and Fisheries 26, 123-133. http://dx.doi.org/10.1007/s11160-015-9413-y

Cooke, S.J., Woodley, C.M., Eppard, M.B., Brown, R.S. \& Nielsen, J.L., 2011, 'Advancing the surgical implantation of electronic tags in fish: A gap analysis and research agenda based on a review of trends in intracoelomic tagging effects studies Reviews in Fish Biology and Fisheries 21, 127-151. http://dx.doi.org/10.1007/ s11160-010-9193-3

Council for International Organization of Medical Sciences/International Council for Laboratory Animal Science, 2012, International guiding principles for biomedical research involving animals, Council for International Organization of Medical Sciences/International Council for Laboratory Animal Science, Geneva.

Council of Europe, 1986, European convention for the protection of vertebrate animals used for experimental and other scientific purposes, European Treaty Series 123 Council of Europe, Strasbourg.

Craig, J.F., 2006, 'Ethical justification for the use and treatment of fishes in research', Journal of Fish Biology 68, 1-2. http://dx.doi.org/10.1111/j.0022-1112.2006. 01035.x

Dalu, T., Wasserman, R.J., Jordaan, M., Froneman, W.P. \& Weyl, O.L., 2015, 'An assessment of the effect of rotenone on selected non-target aquatic fauna' PLoS One 10, e0142140, viewed 24 June 2016, from http://journals.plos.org/ plosone/article?id=10.1371/journal.pone.0142140, http://dx.doi.org/10.1371/ journal.pone. 0142140
Domeier, M.L., Dewar, H. \& Nasby-Lucas, N., 2003, 'Mortality rate of striped marlin (Tetrapturus audax) caught with recreational tackle', Marine and Freshwater Research 54, 435-445. http://dx.doi.org/10.1071/MF01270

Dunlop, S.W., Mann, B.Q. \& Van der Elst, R.P., 2013, 'A review of the Oceanographic Research Institute's Cooperative Fish Tagging Project: 27 years down the line' African Journal of Marine Science 35, 209-221. http://dx.doi.org/10.2989/ 1814232X.2013.769909

Editorial, 2011, 'Ethical justification for the use and treatment of fishes in research: An update', Journal of Fish Biology 78, 393-394.

Editorial, 2012, 'Guidelines for the treatment of animals in behavioural research and teaching', Animal Behaviour 83, 301-309.

Ellender, B.R., Becker, A., Weyl, O.L.F. \& Swartz, E.R., 2012, 'Underwater video analysis as a non-destructive alternative to electrofishing for sampling imperilled headwater stream fishes', Aquatic Conservation: Marine and Freshwater Ecosystems 22(1), 58-65. http://dx.doi.org/10.1002/aqc.1236

Ellender, B.R., Wasserman, R.J., Ndaleni, P.M., Mofu, L., Wu, Y. \& Weyl, O.L.F., 2016 'Reporting by-catch and mortalities in targeted biological field surveys on fishes' Aquatic Conservation: Marine and Freshwater Ecosystems 26(3), 596-601. http:// dx.doi.org/10.1002/aqc.2613

European Union, 2010, 'Directive 2010/63/EU of the European Parliament and of the Council of 22 September 2010 on the protection of animals used for scientific purposes', Official Journal of the European Union 276, 33-79.

Feyrer, F., Portz, D., Odum, D., Newman, K.B., Sommer, T., Contreras, D. et al., 2013, 'SmeltCam: Underwater video codend for trawled nets with an application to the distribution of the imperiled delta smelt', PLoS One 8, e67829. http://dx.doi. org/10.1371/journal.pone.0067829

Filipecki, A.T.P., Machado, C.J.S., Valle, S. \& De Oliveira Teixeira, M., 2011, 'The Brazilian legal framework on the scientific use of animals', ILAR e-Journal 52 e8-e15, viewed 06 June 2016, from http://ilarjournal.oxfordjournals.org/ content/52/1/E8.full.pdf+html

Goodchild, G.A., 1991, Code of practice and guidelines for safety with electric fishing, EIFAC Occasional Paper 24, Food and Agriculture Organisation, Rome.

Guy, C.S., Blankenship, H.L. \& Nielsen, L.A., 1996, 'Tagging and marking', in B.R Murphy \& D.W. Willis (eds.), Fisheries techniques, pp 353-383, American Fisheries Society, Bethesda, MD.

Heupel, M.R. \& Simpfendorfer, C., 2010, 'Science or slaughter: Need for lethal sampling of sharks', The Journal of the Society for Conservation Biology 24 1212-1218. http://dx.doi.org/10.1111/j.1523-1739.2010.01491.x

Holland, K.N., Wetherbee, B.M., Lowe, C.G. \& Meyer, C.G., 1999, 'Movements of tiger sharks (Galeocerdo cuvier) in coastal Hawaiian waters', Marine Biology 134 665-673. http://dx.doi.org/10.1007/s002270050582

Javahery, S. \& Moradlu, A.H., 2012, 'AQUI-S, a new anesthetic for use in fish propagation', Global Veterinaria 9(2), 205-210.

Jepsen, N., Koed, A., Thorstad, E.B. \& Baras, E., 2002, 'Surgical implantation of telemetry transmitters in fish: How much have we learned?, Hydrobiologia 483, 239-248. http://dx.doi.org/10.1023/A:1021356302311

Keniry, J., Brofka, W.A., Horns, W.H. \& Marsden, J.E., 1996, 'Effects of decompression and puncturing the gas bladder on survival of tagged yellow perch', North American Journal of Fisheries Management 16(1), 201-206. http://dx.doi. org/10.1577/1548-8675(1996)016<0201:EODAPT>2.3.CO;2

Kennelly, S.J. \& Gray, C.A., 2000, 'Reducing the mortality of discarded undersize sand whiting Sillago ciliata in an estuarine seine fishery', Marine and Freshwate Research 51(8), 749-753. http://dx.doi.org/10.1071/MF00014

Kilkenny, C., Browne, W.J., Cuthill, I.C., Emerson, M. \& Altman, D.G., 2010, 'Improving bioscience research reporting: The ARRIVE guidelines for reporting animal research', PLoS Biology 8(6), e1000412, viewed 06 June 2016, from https://www. nc3rs.org.uk/arrive-guidelines, http://dx.doi.org/10.1371/journal.pbio.1000412

Knight, A., 2011, 'Weighing the costs and benefits of animal experiments', in Eighth World Congress on Alternatives and Animal Use in the Life Sciences, Alternatives to Animal Experimentation, Proceedings, Montreal, Canada, 21-25 August, 2011 pp. 289-294.

Langlois, T.J., Harvey, E.S., Fitzpatrick, B., Meeuwig, J.J., Shedrawi, G. \& Watson, D.L. 2010, 'Cost-efficient sampling of fish assemblages: Comparison of baited video stations and diver video transects', Aquatic Biology 9, 155-168. http://dx.doi. org/10.3354/ab00235

Lapointe, N.W.R., Corkum, L.D. \& Mandrak, N.E., 2006, 'A comparison of methods for sampling fish diversity in shallow offshore waters of large rivers', North American Journal of Fisheries Management 26, 503-513. http://dx.doi.org/10.1577/M05091.1

Larocque, S.M., Cooke, S.J. \& Blouin-Demers, G., 2012, 'A breath of fresh air: Avoiding anoxia and mortality of freshwater turtles in fyke nets by the use of floats', Aquatic Conservation: Marine and Freshwater Ecosystems 22(2), 198-205. http:// dx.doi.org/10.1002/aqc.1247

Liedtke, T.L. \& Rub, M.W., 2012, 'Techniques for telemetry transmitter attachment and evaluation of transmitter effects on fish performance', in N.S. Adams, J.W. Beeman \& J.H. Eiler (eds.), Telemetry techniques: A user guide for fisheries research, pp. 45-87, American Fisheries Society, Bethesda, MD.

Maggs, J.Q. \& Cowley, P.D., 2016, 'Nine decades of fish movement research in southern Africa: A synthesis of research and findings from 1928 to 2014', Reviews in Fish Biology and Fisheries 26, 287-302. http://dx.doi.org/10.1007/s11160-016$9425-2$

Mallet, D. \& Pelletier, D., 2014, 'Underwater video techniques for observing coastal marine biodiversity: A review of sixty years of publications (1952-2012)', Fisheries Research 154, 44-62. http://dx.doi.org/10.1016/j.fishres.2014.01.019 
McCormick, S.B., 1993, 'Methods for nonlethal gill biopsy and measurement of $\mathrm{Na*}$ K* -ATPase activity', Canadian Journal of Fisheries and Aquatic Sciences 50 , 656-658. http://dx.doi.org/10.1139/f93-075

McFarlane, G.A., Wydoski, R.S. \& Prince, E.O., 1990, 'A historical review of the development of external tags and marks', American Fisheries Science Symposium 7, 9-29.

Metcalfe, J.D. \& Craig, J.F., 2011, 'Ethical justification for the use and treatment of fishes in research: An update', Journal of Fish Biology 78(2), 393-394. http://dx. doi.org/10.1111/j.1095-8649.2010.02900.x

Minteer, B.A, Collins, J.P., Love, K.E. \& Puschendorf, R., 2014, 'Avoiding (re)extinction', Science 344, 260-261. http://dx.doi.org/10.1126/science.1250953

Miya, T., Gon, O., Mwale, M. \& Cheng, C.-H.C., 2014, 'The effect of habitat temperature on serum antifreeze glycoprotein (AFGP) activity in Notothenia rossii (Pisces: Nototheniidae) in the Southern Ocean', Polar Biology 37, 367-373. http://dx.doi. Nototheniidae) in the Southern
org/10.1007/s00300-013-1437-y

Miyamoto, N., Fernández-Manjarrés, J.F., Morand-prieur, M.-E., Bertolino, P. \& Frascaria-Lacoste, N., 2008, 'What sampling is needed for reliable estimations of genetic diversity in Fraxinus excelsior L. (Oleaceae)?', Annals of Forest Science 65, 403-403. http://dx.doi.org/10.1051/forest:2008014

Mohr, B., 2013, 'The current status of laboratory animal ethics in South Africa', Alternatives to laboratory animals 41(4), 48-51.

Murray, D.L. \& Fuller, M.R., 2000, 'A critical review of the effects of marking on the biology of vertebrates', in L. Boitani \& T.K. Fuller (eds.), Research techniques in animal ecology, pp. 15-64, Columbia University Press, New York.

Naef-Daenzer, B., Fruh, D., Stalder, M., Wetli, P. \& Weise, E., 2005, 'Miniaturization (0.2 grams) and evaluation of attachment techniques of telemetry transmitters', Journal of Experimental Biology 208, 4063-4068. http://dx.doi.org/10.1242/ jeb.01870

National Cancer Institute, n.d., Laboratory animal services programme, Frederick National Laboratory for Cancer Research: Animal Care and Use Committee Guidelines, viewed 06 June 2016, from https://ncifrederick.cancer.gov/lasp/Acuc/ Frederick/GuidelinesFnl.aspx

National Research Council, 2011, Guide for the care and use of laboratory animals: Eighth edition, National Academic Press, Washington, DC.

Neiffer, D.L. \& Stamper, N.A., 2009, 'Fish sedation, anesthesia, analgesia, and euthanasia: Considerations, methods, and types of drugs', ILAR Journal 50(4), 343-360. http://dx.doi.org/10.1093/ilar.50.4.343

Nielsen, L.A., 1992, Methods of marking fish and shellfish, American Fisheries Society Special Publication 23, Bethesda, MD.

O'Grady, M.F., 1984, 'The effects of fin-clipping, floy-tagging, and fin-damage on the survival and growth of brown trout (Salmo trutta L.) stocked in Irish lakes', Fish survival and growth of brown trout (Salmo trutta L.) stocked in Irish lakes, Fish
Management 15(2), 49-58. http://dx.doi.org/10.1111/j.1365-2109.1984. tb00408.x

Osborne, N.J., Payne, D. \& Newman, M.L., 2009, 'Journal editorial policies, animal welfare, and the 3Rs', The American Journal of Bioethics 9(12), 55-59. http:// dx.doi.org/10.1080/15265160903318343

Prince, E.D., Snodgrass, D., Orbesen, E.S., Hoolihan, J.P., Serafy, J.E. \& Schratweiser J.E., 2007, 'Circle hooks, "J" hooks and drop-back time: A hook performance study of the south Florida recreational live-bait fishery for sailfish', Istiophorus platypterus', Fisheries Management and Ecology 14, 173-182.

Russell, W.M.S. \& Burch, R.L., 1959, The principles of humane experimental technique, Methuen, London.

Satheeshkumar, P., Ananthan, G., Senthilkumar, D., Khan, A.B. \& Jeevanantham, K., 2012 , 'Comparative investigation on haematological and biochemical studies on wild marine teleost fishes from Vellar Estuary, southeast coast of India', Comparative Clinical Pathology 21, 275-281.
Schaeffer, J. \& Hoffman, E., 2002, 'Performance of barbless hooks in a marine recreational fishery' North American Journal of Fisheries Management 22 229-235.http://dx.doi.org/10.1577/1548-8675(2002)022<0229:POBABH>2.0.CO;2

Shahi, N., Yousuf, A.R., Rather, M.I., Ahmad, F. \& Yaseen, T., 2013, 'First report of blood parasites in fishes from Kashmir and their effect on the haematological profile', Open Veterinary Journal 3(2), 89-95.

Snyder, D.E., 2003, Electrofishing and its harmful effects on fish, Information and Technology Report 2003-0002, U.S. Geological Survey, Denver, CO.

Society of Environmental Toxicology and Chemistry, n.d., SETAC code of ethics, viewed 06 June 2016, from https://www.setac.org/?page=SETACEthics

South African Bureau of Standards, 2008, The care and use of animals for scientific purposes, South African National Standard 10386, SABS Standards Division, Groenkloof.

South African Government, 1982, Veterinary and Para-Veterinary Professions Act (Act No. 19 of 1982), South African Government, Pretoria.

Stasko, A.B. \& Pincock, D.G., 1977, 'Review of underwater biotelemetry, with emphasis on ultrasonic techniques', Journal of the Fisheries Research Board of Canada 34(9), 1261-1285. http://dx.doi.org/10.1139/f77-189

Stoskopf, M.K., 1993, 'Fish medicine', Saunders, Philadelphia, PA.

Thorstad, E.B., Rikardsen, A.H., Alp, A. \& Ökland, F., 2013, 'The use of electronic tags in fish research', Turkish Journal of Fisheries and Aquatic Sciences 13, 881-896.

Thorsteinsson, V., 2002, Tagging methods for stock assessment and research in fisheries, Report of Concerted Action FAIR CT.96.1394 (CATAG), Marine Research Institute Technical Report 79, Reykjavik.

United Kingdom Government, 1986, 'Animals (Scientific Procedures) Act', Her Majesty's Stationery Office, London.

Use of Fishes in Research Committee (Joint Committee of the American Fisheries Society, the American Institute of Fishery Research Biologists, and the American Society of Ichthyologists and Herpetologists), 2014, Guidelines of the use of fishes in research, American Fisheries Society, Bethesda, MD.

Wagner, G.N. \& Cooke, S.J., 2005, 'Methodological approaches and opinions of researchers involved in the surgical implantation of telemetry transmitters in fish' Journal of Aquatic Animal Health 17(2), 160-169. http://dx.doi.org/10.1577/ H04-037.1

Willis, T.J., 2001, 'Visual census methods underestimate density and diversity of cryptic reef fishes', Journal of Fish Biology 59, 1408-1411. http://dx.doi org/10.1111/j.1095-8649.2001.tb00202.x

Willis, T.J., Millar, R.B. \& Babcock, R.C., 2000, 'Detection of spatial variability in relative density of fishes: Comparison of visual census, angling and baited underwater video', Marine Ecology Progress Series 198, 249-260. http://dx.doi.org/10.3354/ meps198249

Winger, P.D. \& Walsh, S.J., 2001, 'Tagging of Atlantic cod (Gadus morhua) with intragastric transmitters: Effects of forced insertion and voluntary ingestion on retention, food consumption and survival', Journal of Applied Ichthyology 17, 234-239. http://dx.doi.org/10.1046/j.1439-0426.2001.00280.x

Winter, J., 1996, 'Advances in underwater biotelemetry', in B.R. Murphy \& D.W. Willis (eds.), Fisheries techniques, pp. 555-590, American Fisheries Society, Bethesda, MD.

Woodall, L.C., Koldewey, H.J. \& Shaw, P.W., 2011, 'Serial monogamy in the European long-snouted seahorse Hippocampus guttulatus', Conservation Genetics 12(6), 1645-1649. http://dx.doi.org/10.1007/s10592-011-0253-6

World Medical Association, 2008, Declaration of Helsinki: Ethical principles for medical research involving human subjects, World Medical Association, Helsinki. 


\section{Appendix 1}

TABLE 1-A1: Categorisation, based on animal ethical requirements, of 250 ISIrated, peer-reviewed, scientific journals with the most articles relating to fish research, revealed through a Web of Science (Thomson Reuters) search.

Journal

Category

ACTA ICHTHYOLOGICA ET PISCATORIA

ACTA PARASITOLOGICA

egory

AFRICAN JOURNAL OF AQUATIC SCIENCE

AFRICAN JOURNAL OF ECOLOGY

AFRICAN JOURNAL OF MARINE SCIENCE

AFRICAN ZOOLOGY

AMBIO

AMERICAN MIDLAND NATURALIST

AMERICAN NATURALIST

AMERICAN ZOOLOGIST

ANIMAL BEHAVIOUR

ANNALES ZOOLOGICI FENNICI

ANNALS OF THE NEW YORK ACADEMY OF SCIENCES

ANTARCTIC SCIENCE

APPLIED AND ENVIRONMENTAL MICROBIOLOGY

AQUACULTURE

AQUACULTURE RESEARCH

AQUATIC BIOLOGY

AQUATIC CONSERVATION MARINE AND FRESHWATER

ECOSYSTEMS

AQUATIC ECOLOGY

4

3

3

4

4

1

4

1

AQUATIC ECOSYSTEM HEALTH MANAGEMENT

AQUATIC INVASIONS

AQUATIC LIVING RESOURCES

AQUATIC SCIENCES

AQUATIC TOXICOLOGY

ARCHIV FUR FÜR HYDROBIOLOGIE/FUNDAMENTAL AND

APPLIED LIMNOLOGY

ARCHIVES OF ENVIRONMENTAL AND OCCUPATIONAL HEALTH

ARCTIC

ARDEA

AUSTRALIAN JOURNAL OF ECOLOGY

AUSTRALIAN JOURNAL OF MARINE AND FRESHWATER

RESEARCH

AUSTRALIAN JOURNAL OF ZOOLOGY

BEHAVIORAL ECOLOGY

BEHAVIORAL ECOLOGY AND SOCIOBIOLOGY

BEHAVIOUR

BIODIVERSITY AND CONSERVATION

BIOLOGICAL CONSERVATION

BIOLOGICAL INVASIONS

BIOLOGICAL JOURNAL OF THE LINNEAN SOCIETY

BIOLOGY LETTERS

BIOLOGY OF REPRODUCTION

BIOSCIENCE

BIOTA NEOTROPICA

BMC EVOLUTIONARY BIOLOGY

BMC GENOMICS

BRAIN BEHAVIOR AND EVOLUTION

BRAZILIAN ARCHIVES OF BIOLOGY AND TECHNOLOGY

BRAZILIAN JOURNAL OF BIOLOGY

BRAZILIAN JOURNAL OF OCEANOGRAPHY

BULLETIN FRANCAIS DE LA PECHE ET DE LA PISCICULTURE/

KNOWLEDGE AND MANAGEMENT OF AQUATIC ECOSYSTEMS

BULLETIN OF MARINE SCIENCE

CAHIERS DE BIOLOGIE MARINE

CALIFORNIA COOPERATIVE OCEANIC FISHERIES

INVESTIGATIONS REPORTS

CANADIAN FIELD NATURALIST

$\begin{array}{ll} & 4 \\ & 4 \\ & 4 \\ & 3\end{array}$

Appendix Table 1-A1 continues $\rightarrow$
TABLE 1-A1 (Continues...): Categorisation, based on animal ethical requirements, of 250 ISI-rated, peer-reviewed, scientific journals with the most articles relating to fish research, revealed through a Web of Science (Thomson Reuters) search. Journal

CANADIAN JOURNAL OF FISHERIES AND AQUATIC SCIENCES

CANADIAN JOURNAL OF ZOOLOGY REVUE CANADIENNE DE Category ZOOLOGIE

CANCER GENETICS AND CYTOGENETICS

CIENCIAS MARINAS

COLONIAL WATERBIRDS

COMPARATIVE BIOCHEMISTRY AND PHYSIOLOGY A

MOLECULAR INTEGRATIVE PHYSIOLOGY

COMPARATIVE BIOCHEMISTRY AND PHYSIOLOGYC

TOXICOLOGY AND PHARMACOLOGY

COMPARATIVE PARASITOLOGY

1

CONDOR

CONSERVATION BIOLOGY

CONSERVATION GENETICS

COPEIA

CORAL REEFS

CRUSTACEANA

CYBIUM

DEEP SEA RESEARCH PART I OCEANOGRAPHIC RESEARCH

1

PAPERS

DEEP SEA RESEARCH PART I TOPICAL STUDIES IN

OCEANOGRAPHY

DISEASES OF AQUATIC ORGANISMS

3

4

4

1

DIVERSITY AND DISTRIBUTIONS

ECOGRAPHY

ECOHYDROLOGY

ECOLOGICAL APPLICATIONS

ECOLOGICAL ENGINEERING

ECOLOGICAL INDICATORS

ECOLOGICAL MODELLING

ECOLOGICAL MONOGRAPHS

ECOLOGY

ECOLOGY AND EVOLUTION

ECOLOGY AND SOCIETY

ECOLOGY LETTERS

ECOLOGY OF FRESHWATER FISH

ECOSPHERE

ECOSYSTEMS

ECOTOXICOLOGY

EMU

ENVIRONMENTAL BIOLOGY OF FISHES

ENVIRONMENTAL MANAGEMENT

ENVIRONMENTAL MICROBIOLOGY

ENVIRONMENTAL MONITORING AND ASSESSMENT

3

4

2

4

3

4

4

4

3

3

2

2

2

4

2

ENVIRONMENTAL POLLUTION

ENVIRONMENTAL SCIENCE TECHNOLOGY

ENVIRONMENTAL TOXICOLOGY AND CHEMISTRY

ESTUARIES

ESTUARIES AND COASTS

ESTUARINE COASTAL AND SHELF SCIENCE

EVOLUTION

EVOLUTIONARY ECOLOGY

EVOLUTIONARY ECOLOGY RESEARCH

FEMS MICROBIOLOGY ECOLOGY

FISH AND FISHERIES

FISH PHYSIOLOGY AND BIOCHEMISTRY

FISHERIES

FISHERIES MANAGEMENT AND ECOLOGY

FISHERIES OCEANOGRAPHY

Appendix Table 1-A1 continues next page $\rightarrow$ 
TABLE 1-A1 (Continues...): Categorisation, based on animal ethical requirements, of $250 \mathrm{ISI}$-rated, peer-reviewed, scientific journals with the most articles relating to fish research, revealed through a Web of Science (Thomson Reuters) search. Journal Category

FISHERIES RESEARCH

FISHERIES SCIENCE

FISHERY BULLETIN

FOLIA PARASITOLOGICA

FOLIA ZOOLOGICA

FRESHWATER BIOLOGY

FRESHWATER SCIENCE

FUNCTIONAL ECOLOGY

GENE

GENERAL AND COMPARATIVE ENDOCRINOLOGY

GENES CHROMOSOMES CANCER

GLOBAL CHANGE BIOLOGY

GLOBAL ECOLOGY AND BIOGEOGRAPHY

HELGOLAND MARINE RESEARCH

HEREDITY

HUMAN ECOLOGY

HYDROBIOLOGIA

IBIS

ICES JOURNAL OF MARINE SCIENCE

ICHTHYOLOGICAL RESEARCH

IHERINGIA SERIE ZOOLOGIA

INDIAN JOURNAL OF FISHERIES

INTEGRATIVE AND COMPARATIVE BIOLOGY

INTERCIENCIA

INTERNATIONAL JOURNAL FOR PARASITOLOGY

INTERNATIONAL JOURNAL OF FOOD MICROBIOLOGY

INTERNATIONAL REVIEW OF HYDROBIOLOGY

IRANIAN JOURNAL OF FISHERIES SCIENCES

ITALIAN JOURNAL OF ZOOLOGY

JOURNAL OF ANIMAL ECOLOGY

JOURNAL OF APPLIED ECOLOGY

JOURNAL OF APPLIED ICHTHYOLOGY

JOURNAL OF ARCHAEOLOGICAL SCIENCE

JOURNAL OF BIOGEOGRAPHY

JOURNAL OF CHEMICAL ECOLOGY

JOURNAL OF COMPARATIVE PHYSIOLOGY B BIOCHEMICA

SYSTEMIC AND ENVIRONMENTAL PHYSIOLOGY

JOURNAL OF CRUSTACEAN BIOLOGY

JOURNAL OF EVOLUTIONARY BIOLOGY

JOURNAL OF EXPERIMENTAL BIOLOGY

JOURNAL OF EXPERIMENTAL MARINE BIOLOGY AND ECOLOGY

JOURNAL OF EXPERIMENTAL ZOOLOGY

JOURNAL OF FISH BIOLOGY

JOURNAL OF FISH DISEASES

JOURNAL OF FRESHWATER ECOLOGY

JOURNAL OF GREAT LAKES RESEARCH

JOURNAL OF HELMINTHOLOGY

JOURNAL OF HEREDITY

JOURNAL OF HERPETOLOGY

JOURNAL OF MARINE SYSTEMS

JOURNAL OF MORPHOLOGY

JOURNAL OF NATURAL HISTORY

JOURNAL OF PARASITOLOGY

JOURNAL OF PLANKTON RESEARCH

JOURNAL OF RAPTOR RESEARCH

JOURNAL OF SEA RESEARCH

JOURNAL OF SHELLFISH RESEARCH

JOURNAL OF THE AMERICAN WATER RESOURCES

ASSOCIATION

JOURNAL OF THE MARINE BIOLOGICAL ASSOCIATION OF THE

UNITED KINGDOM

1

3

4

4

2

1

3

1

2

2

2

1

4

2

1

4

3

1

1

4

3

4

3

.

(n)

(

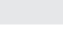

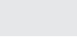

TABLE 1-A1 (Continues...): Categorisation, based on animal ethical requirements, of 250 ISI-rated, peer-reviewed, scientific journals with the most articles relating to fish research, revealed through a Web of Science (Thomson Reuters) search.

Journal Category

JOURNAL OF THE NORTH AMERICAN BENTHOLOGICAL 3

SOCIETY

JOURNAL OF THEORETICAL BIOLOGY

JOURNAL OF TROPICAL ECOLOGY

JOURNAL OF ZOOLOGY

KNOWLEDGE AND MANAGEMENT OF AQUATIC ECOSYSTEMS

LANDSCAPE ECOLOGY

LATIN AMERICAN JOURNAL OF AQUATIC RESEARCH

LIMNOLOGICA

LIMNOLOGY AND OCEANOGRAPHY

MARINE AND COASTAL FISHERIES

MARINE AND FRESHWATER BEHAVIOUR AND PHYSIOLOGY

MARINE AND FRESHWATER RESEARCH

MARINE BIOLOGY

MARINE BIOLOGY RESEARCH

MARINE ECOLOGY AN EVOLUTIONARY PERSPECTIVE

MARINE ECOLOGY PROGRESS SERIES

MARINE ECOLOGY PUBBLICAZIONI DELLA STAZIONE

ZOOLOGICA DI NAPOLII

MARINE ENVIRONMENTAL RESEARCH

MARINE GENOMICS

MARINE MAMMAL SCIENCE

MARINE POLICY

MARINE POLLUTION BULLETIN

MEMORIAS DO INSTITUTO OSWALDO CRUZ

METHODS IN ECOLOGY AND EVOLUTION

MOLECULAR BIOLOGY AND EVOLUTION

MOLECULAR ECOLOGY

MOLECULAR ECOLOGY RESOURCES

MOLECULAR PHYLOGENETICS AND EVOLUTION

NATURE

NATURWISSENSCHAFTEN

NEOTROPICAL ICHTHYOLOGY

NETHERLANDS JOURNAL OF SEA RESEARCH

NEW ZEALAND JOURNAL OF MARINE AND FRESHWATER

RESEARCH

NORTH AMERICAN JOURNAL OF AQUACULTURE

4

1

4

3

3

4

2

4

1

4

NORTH AMERICAN JOURNAL OF FISHERIES MANAGEMENT

NORTHWEST SCIENCE

OCEAN COASTAL MANAGEMENT

OCEANOGRAPHY AND MARINE BIOLOGY

OECOLOGIA

OIKOS

PAKISTAN JOURNAL OF ZOOLOGY

PARASITOLOGY

PARASITOLOGY RESEARCH

PHILOSOPHICAL TRANSACTIONS OF THE ROYAL SOCIETY B BIOLOGICAL SCIENCES

PLOS ONE

POLAR BIOLOGY

PROCEEDINGS OF THE NATIONAL ACADEMY OF SCIENCES OF THE UNITED STATES OF AMERICA

PROCEEDINGS OF THE ROYAL SOCIETY B BIOLOGICAL SCIENCES

REGULATED RIVERS RESEARCH MANAGEMENT

RESTORATION ECOLOGY

1

REVIEWS IN FISH BIOLOGY AND FISHERIES

REVIEWS IN FISHERIES SCIENCE

REVISTA BRASILEIRA DE PARASITOLOGIA VETERINARIA

REVISTA BRASILEIRA DE ZOOLOGIA

REVISTA CHILENA DE HISTORIA NATURAL

REVISTA DE BIOLOGIA MARINA Y OCEANOGRAFIA

Appendix Table 1-A1 continues next page $\rightarrow$ 
TABLE 1-A1 (Continues...): Categorisation, based on animal ethical requirements, of 250 ISI-rated, peer-reviewed, scientific journals with the most articles relating to fish research, revealed through a Web of Science (Thomson Reuters) search.

Journal Category

REVISTA DE BIOLOGIA TROPICAL 4

RIVER RESEARCH AND APPLICATIONS

SARSIA

SCIENCE OF THE TOTAL ENVIRONMENT

SCIENTIA MARINA

SCIENTIFIC REPORTS

SOUTH AFRICAN JOURNAL OF ZOOLOGY

SOUTHEASTERN NATURALIST

SOUTHWESTERN NATURALIST

STUDIES ON NEOTROPICAL FAUNA AND ENVIRONMENT

SYSTEMATIC BIOLOGY

SYSTEMATIC PARASITOLOGY 2

THERIOGENOLOGY

TRANSACTIONS OF THE AMERICAN FISHERIES SOCIETY

TURKISH JOURNAL OF FISHERIES AND AQUATIC SCIENCES

TURKISH JOURNAL OF VETERINARY ANIMAL SCIENCES

VETERINARY PARASITOLOGY

VIE ET MILIEU LIFE AND ENVIRONMENT 4

WATER SCIENCE AND TECHNOLOGY 4

WATERBIRDS

WESTERN NORTH AMERICAN NATURALIST

WETLANDS

WETLANDS ECOLOGY AND MANAGEMENT 3

WILDLIFE RESEARCH

ZEBRAFISH

ZOOLOGIA

ZOOLOGICAL STUDIES

ZOOTAXA

Category 1, journal/publisher specifies a particular set (or sets) of animal ethics/care guidelines to which the manuscript is required to adhere; Category 2, journal/publisher guidelines to which the manuscript is required to adhere; Category 2, journal/publisher
requires for publication that the research was approved by an institutional, national or international animal ethics committee; Category 3, the journal/publisher requires that the author makes a statement on the welfare of the study animals; Category 4, journal/publisher has no mention of ethics, or treatment of animals, or ethical requirements. 


\section{Appendix 2}

TABLE 1-A2: Web links to guiding documents, policies and legislation for the ethical treatment of animals in research, identified by 45 ISI-rated journals, in their instructions to authors.

Guiding document/policy/legislation Link to resource

National Centre for the Replacement, Refinement and Reduction of Animals in https://www.nc3rs.org.uk/arrive-guidelines

Research: ARRIVE (Animal Research: Reporting of in Vivo Experiments) Guidelines https://www.elsevier.com/_data/promis_misc/ASAB2006.pdf

Animal Behaviour Journal: Guidelines for the treatment of animals in behavioural research and teaching

World Medical Association: Declaration of Helsinki

http://www.wma.net/en/30publications/10policies/b3/

Council for International Organization of Medical Sciences/International Council for Laboratory Animal Science: International Guiding Principles for Biomedical Research Involving Animals

Basel Declaration Society: Basel Declaration (2010)

https://grants.nih.gov/grants/olaw/Guiding_Principles_2012.pdf

European Commission: Directive 2010/63/EU on the protection of animals used for scientific purposes

United Kingdom Government: Animals (Scientific Procedures) Act 1986 (revised 2013)

Canadian Council on Animal Care: Guidelines on: the care and use of fish in research, teaching and testing

Society of Environmental Toxicology and Chemistry: Code of Ethics

http://www.basel-declaration.org/

http://ec.europa.eu/environment/chemicals/lab_animals/legislation_en.htm

https://www.gov.uk/guidance/research-and-testing-using-animals http://www.ccac.ca/en_/

National Cancer Institute, Frederick National Laboratory for Cancer Research: Animal Care and Use Committee Guidelines

Journal of Fish Biology: Ethical justification for the use and treatment of fishes in research

American Fisheries Society: Guidelines for the use of Fishes in Research

https://www.setac.org/?page=SETACEthics

https://ncifrederick.cancer.gov/lasp/Acuc/Frederick/GuidelinesFnl.aspx

The National Academies: The Brazilian Legal Framework on the Scientific Use of Animals

Council of Europe: European Convention for the Protection of Vertebrate Animals used for Experimental and Other Scientific Purposes

National Research Council: Guide for the Care and Use of Laboratory Animals

https://www.editorialmanager.com/jfb/account/2011\%20Ethics\%20update $\% 20 \mathrm{j}$. 1095-8649.2010.02900.x.pdf

http://fisheries.org/docs/wp/Guidelines-for-Use-of-Fishes.pdf

http://www.fiocruz.br/omsambiental/media/ArtigolLARv5201eFilipecki.pdf

https://rm.coe.int/CoERMPublicCommonSearchServices/DisplayDCTMContent?documentld $=090000168007 \mathrm{a} 67 \mathrm{~b}$

https://grants.nih.gov/grants/olaw/Guide-for-the-Care-and-use-of-laboratory-animals.pdf 